\title{
제 2차 포스트 부산 임시그룹(PBIG) 회의
}

\section{I . 회의개요}

제 1차 '부산 글로벌 파트너십’ 체제 논의를 위한 1차 쉐르파 회의가 2012년 2월 13일부터 14 일까지 파리 $\mathrm{OECD}$ 본부에서 개최 되었다. 이어 제 2차 포스트 부산 임시그룹(Post Busan Interim Group) 회의가 2012년 4월 4일부터 5일까지 파리 OECD 본부에서 개최 되었다.

\section{II . 주요내용}

- (부산 파트너심 운영방안) 장관급 회의의 주요 기능, 개최 주기, 장소 및 장관급 회의를 지 원 할 집행 위원회의 핵심 기능 및 구성원 규모에 대해 합의하고, OECD-UNDP 공동 지 원팀 운영방안을 협의함.

- 장관급 회의 주 목적을 '부산총회 합의 이행' 뿐만 아니라 Rio+20 및 post-MDG 논의 등 새롭게 부상하는 이슈를 다룰 수 있도록 ‘효과적인 개발협력을 위한 기회 모색' 을 주 요 기능으로 추가, 변화하는 개발 환경에 대응 할 수 있는 신축성을 부여

- 장관급 회의는 19 24개월 주기로 개최, 1차 회의는 2013년 상반기로 참정 추진하고, 개 최 장소는 $\mathrm{OECD}, \mathrm{UN}$, 세계은행 고위급 회의와 연계 방식 등은 포함하여 탄력적으로 검토

- 집행위원회 그룹 대표성과 개인 능력을 고려하여 12 14명 규모로 구성

- 집행위원회 의장단(공여국, 수원국, 신흥국 대표 3명)은 6월 원조효과작업반 회의에서 선정

- (글로벌 모니터링) 부산총회에서 합의된 4대 공통 원칙을 기반으로 글로벌 모니터링 대상 분야 7 개를 선정하고, 각 분야별 부산총회 핵심 공약사항 이행을 모니터링 할 10 개 수준의 글로벌 지표를 선정키로 함.

- 7개 분야: 결과중심, 포괄적인 주인의식 및 파트너십, 투명성, 예측성, 양성평등, 역량배양

- 남남협력 제공국의 자발적인 모니터링 체제 참여 원칙 재확인 